\title{
PEMANFAATAN KOTORAN TERNAK DAN PENGENDALI HAYATI HAMA TANAMAN KELAPA RAKYAT DI KECAMATAN WULUHAN KABUPATEN JEMBER 1)
}

\author{
Dyah Nuning Erawati2), Irma Wardati ${ }^{3)}$ Cherry Triwidiarto4) \\ 1) Dibiayai Dikti Nomor: 090/SP2H/PPM/DIT.LITABMAS/II/2015 \\ 2) 3) 4) Jurusan Produksi Pertanian Politeknik Negeri Jember
}

\begin{abstract}
ABSTRAK
Kegiatan ini dilaksanakan di Desa Lojejer Kecamatan Wuluhan Kabupaten Jember dengan mitra adalah petani penderes nira kelapa rakyat yang tergabung dalam dua kelompok tani, yaitu kelompok tani Rekesan Kepel dan kelompok tani Sulakdoro. Produksi utama petani adalah gula merah dari nira kelapa sehingga budidaya kelapa merupakan sumber penghasilan yang utama untuk mayoritas penduduk. Kegiatan budidaya kelapa rakyat seringkali terkendala serangan hama kumbang kelapa (Oryctes rhinoceros) sehingga produktivitas tanaman tidak bisa dicapai dengan optimal.

Pengendalian hama dengan insektisida kimiawi akan memberikan dampak positif dengan matinya hama tetapi menimbulkan dampak negatif mengganggu keseimbangan lingkungan. Oleh karena itu, diperlukan alternatif pengendalian yang lebih aman dan berwawasan lingkungan, dengan menggunakan cendawan entomopatogen seperti Metarrhizium anisopliae. Sedangkan limbah kotoran ternak bisa dikembangkan menjadi pupuk organik yang akan meningkatkan kesuburan tanah sekaligus menekan dampak negatif penumpukan kotoran ternak yang belum termanfaatkan secara optimal. Produk pupuk organik plus pengendali hayati yang akan dikembangkan juga membuka peluang wirausaha baru di bidang produk pupuk organik dan pengendali hama kumbang kelapa yang berwawasan lingkungan.

Hasil kegiatan menunjukkan bahwa: (1) Pengembangan pupuk organik plus pengendali hayati sesuai diterapkan sekaligus membuka peluang wirausaha baru bagi mitra, (2) Pembekalan pengetahuan, pembekalan keterampilan serta demo plot mengenai pengembangan pupuk organik plus pengendali hayati mendapat tanggapan yang baik dan antusias yang tinggi dari mitra, dan (3) Tujuan dari kegiatan sudah tercapai dan sesuai dengan kerangka pemecahan masalah yang telah dirumuskan meskipun masih terdapat kendala yang dapat diantisipasi melalui forum komunikasi dan latihan yang berkesinambungan dari khalayak sasaran dengan didukung oleh pembinaan dari pihak yang terkait.
\end{abstract}

Kata kunci: kelapa, kotoran ternak, pengendali hayati

\section{PENDAHULUAN}

Kecamatan Wuluhan merupakan wilayah tanaman kelapa di Kabupaten Jember dengan jarak $35 \mathrm{~km}$ ke arah selatan dari ibukota kabupaten. Menurut Badan Pusat Statistik Kabupaten Jember (2013), bahwa secara geografis Kecamatan Wuluhan terletak pada ketinggian 0-500 meter diatas permukaan laut dengan luas wilayah 137,18 $\mathrm{km}^{2}$. Jumlah penduduk di Kecamatan Wuluhan sebanyak 114.695 jiwa dengan kepadatan penduduk rata-rata 836 jiwa/ $\mathrm{km}^{2}$. Sebagian besar penduduk bekerja di bidang pertanian (59,38\%), sedangkan penduduk yang bekerja di bidang perdagangan, industri, jasa dan lainnya berturut-turut 15,57\%, 5,95\%, 13,51\% dan 5,58\%. Budidaya kelapa merupakan salah satu kegiatan utama di bidang pertanian selain budidaya padi dan jagung. Luas areal tanaman kelapa 
adalah $1.259,84$ ha dengan luas areal TBM 315,76 ha, luas areal TM 939,13 ha dan luas areal TT 4,95 ha serta produktivitas tanaman rata-rata 8,31 kwintal/ha dengan produksi sebesar 7.801 kwintal.

Kegiatan budidaya kelapa rakyat di Kecamatan Wuluhan seringkali terkendala serangan hama kumbang kelapa (Oryctes rhinoceros) sehingga produktivitas tanaman tidak bisa dicapai dengan optimal. Petani umumnya menggunakan cara kimiawi untuk mengatasi hama. Pengendalian hama dengan insektisida kimiawi akan memberikan dampak positif dengan matinya hama tetapi menimbulkan dampak negatif yang dapat mengganggu keseimbangan lingkungan, yang disebabkan oleh residu yang tinggi pada komponen produksi dan ekosistem (Erawati, 2012).

Oleh karena itu, kelompok tani kelapa rakyat di Kecamatan Wuluhan memerlukan alternatif pengendalian yang lebih aman dan berwawasan lingkungan, antara lain dengan memanfaatkan pengendali hayati. Pengendalian hayati dengan menggunakan cendawan entomopatogen seperti Metarrhizium anisopliae merupakan salah satu alternatif pemecahan masalah karena pemanfaatan pengendali hayati bersifat lebih ramah lingkungan dan dapat menekan populasi hama serta intensitas kerusakan tanaman yang pada gilirannya akan meningkatkan produktivitas tanaman.

Kegiatan dilaksanakan di Desa Lojejer Kecamatan Wuluhan Kabupaten Jember. Mitra kegiatan ini adalah petani penderes nira kelapa rakyat yang tergabung dalam dua kelompok tani, yaitu kelompok tani Rekesan Kepel dan kelompok tani Sulakdoro dengan perwakilan anggota kelompok masingmasing sebanyak 4 orang. Penghasilan utama adalah dari kegiatan budidaya kelapa dan belum memanfaatkan limbah kotoran ternak yang banyak terdapat pada lokasi mitra karena selain sebagai petani juga sebagai peternak sapi, kambing dan burung puyuh. Limbah kotoran ternak bisa dikembangkan menjadi pupuk organik yang akan meningkatkan kesuburan tanah sekaligus memanfaatkan kotoran ternak yang belum dikelola secara optimal.

Beberapa permasalahan yang dihadapi oleh mitra dalam kegiatan memanfaatkan pengendali hayati dan limbah kotoran ternak di Wuluhan Jember, antara lain:

1. Belum terdapat transfer teknologi tepat guna yang mudah diterapkan oleh petani kelapa untuk mengatasi rendahnya produktivitas tanaman akibat serangan hama kumbang tanaman kelapa.

2. Belum diketahui secara luas pemanfaatan pengendali hayati Metarhizium anisopliae sebagai alternatif pengendali hama secara alami yang akan mengurangi pemakaian pestisida kimia

3. Belum dimanfaatkan secara optimal pemanfaatan limbah kotoran ternak sebagai pupuk organik yang bersifat lebih ramah lingkungan

\section{TARGET DAN LUARAN}

Tabel 1. Jenis Luaran dan Indikatornya

\begin{tabular}{|c|l|c|}
\hline No. & \multicolumn{1}{|c|}{ Jenis Luaran } & $\begin{array}{c}\text { Indikator } \\
\text { Capaian }\end{array}$ \\
\hline 1. & $\begin{array}{l}\text { Publikasi ilmiah di } \\
\text { jurnal/prosiding }\end{array}$ & Published \\
\hline 2. & $\begin{array}{l}\text { Peningkatan } \\
\text { pemahaman dan } \\
\text { keterampilan } \\
\text { masyarakat }\end{array}$ & Ada \\
\hline 3. & $\begin{array}{l}\text { Jasa, model, rekayasa } \\
\text { sosial, sistem, } \\
\text { produk/barang }\end{array}$ & Produk \\
\hline
\end{tabular}

\section{METODE PELAKSANAAN}

Metode yang digunakan dalam pelaksanaan kegiatan ini adalah metode 
ceramah, pelatihan dan demonstrasi yang terbagi dalam 5 tahap, yaitu:

\section{Penyuluhan}

Kegiatan penyuluhan ini bertujuan untuk memberikan pengetahuan dan pemahaman kepada mitra sebagai petani penderes nira kelapa sekaligus sebagai peternak (sapi atau kambing). Petani diarahkan untuk memahami tentang penerapan teknologi konservasi tanah dengan memanfaatkan limbah industri pertanian yang banyak terdapat di lokasi mitra. Dijelaskan pula mengenai upaya untuk menekan serangan hama kumbang tanaman kelapa dengan memanfaatkan pengendali hayati sehingga mengurangi ketergantungan petani terhadap pestisida sintetik.

\section{Pelatihan}

Kegiatan pelatihan ini bertujuan untuk meningkatkan keterampilan petani mitra dalam membuat pupuk organik dengan bahan baku berupa limbah industri pertanian yang ada di sekitar lahan budidaya dan sisa pakan ternak sebagai bahan baku utama. Pelatihan juga dilakukan untuk meningkatkan keterampilan petani dalam perbanyakan pengendali hayati $M$. anisopliae

3. Demplot Pencampuran Pupuk Organik dan Pengendali Hayati

Kegiatan demoplot ini bertujuan untuk memberi contoh secara langsung kepada petani mitra tentang cara pencampuran pupuk organik yang dihasilkan dari pengelolaan limbah pertanian dan limbah kotoran ternak dengan pengendali hayati hasil perbanyakan petani mitra secara mandiri.

\section{Pendampingan}

Kegiatan pendampingan petani mitra ini bertujuan untuk mendampingi dan membimbing serta memberi petunjuk teknis pelaksanaan pembuatan pupuk organik, perbanyakan pengendali hayati, pencampuran pupuk organik plus pengendali hayati dan pengemasan.
Dalam pelaksanaan kegiatan ini, pelaksana memonitor setiap tahapan kegiatan agar pelaksanaan di lapang berjalan sesuai dengan tujuan yang telah ditetapkan.

\section{Evaluasi}

Selama berlangsungnya kegiatan tim pelaksanaan program selalu melakukan evaluasi dan bertanggung jawab terhadap pelaksanaan kegiatan pengabdian ini. Untuk selanjutnya dijalin kerja sama antara mitra dengan pihak Politeknik Negeri Jember secara berkelanjutan.

\section{HASIL DAN PEMBAHASAN}

Pelaksanaan kegiatan ini diikuti oleh 8 orang petani kelapa rakyat yang mewakili kelompok tani Rekesan Kepel dan Sulakdoro. Hasil kegiatan diharapkan dapat menjadikan mitra mengembangkan produk pupuk organik plus pengendali hayati yang pada akhirnya bisa diteruskan kepada semua anggota kelompok tani sehingga pengembangan dan transfer ipteks berkelanjutan.

Pemetaan potensi wilayah diperlukan untuk dapat melengkapi potensi SDA dan SDM lebih detil dan lengkap di wilayah mitra agar pelaksanaan kegiatan berjalan lancar sesuai usulan, dengan hasil sebagai berikut:

a. Komoditi utama yang diusahakan oleh petani kelapa rakyat adalah tanaman kelapa yang dideres niranya untuk dijadikan bahan baku gula kelapa.

b. Rata-rata petani memiliki tanaman kelapa 25-50 pohon serta ternak sapi atau kambing dan burung puyuh.

c. Tingkat pendidikan petani adalah SD, SMA dan Diploma dengan mayoritas jenjang pendidikan tertinggi pada tingkat SD.

d. Hama yang sering menyerang tanaman kelapa adalah ulat api (Setora nitens dan Darma trima), ulat kantong (Metisa plana, Cremastopsyche pendula dan 
Mahasena corbetti) dengan hama utama yaitu kumbang badak (Oryctes rhinoceros). Serangan kumbang badak mencapai $90-95 \%$ dari seluruh populasi tanaman kelapa di lokasi mitra.

e. Cara pengendalian yang biasa dilakukan oleh para petani adalah secara kimiawi dengan penggunaan kapur ajaib, garam atau Furadan

f. Pengembangan pengendali hayati: masih sangat terbatas dan belum mengenal jenis pengendali hayati

g. Produksi nira turun karena:

1. Musim kemarau

2. Serangan kumbang badak (wangwung)

3. Tidak pernah dipupuk

h. Potensi limbah pertanian: limbah jerami dan kawul jerami serta kotoran ternak belum dimanfaatkan untuk pupuk organik

\section{Pembekalan Pengetahuan}

\section{A. Penyuluhan Pemanfaatan Pengendali Hayati}

Pembekalan pengetahuan berupa ceramah mengenai hama tanaman kelapa dan cara pengendaliannya selama dalam proses budidaya. Sedangkan ceramah tentang pemanfaatan pengendali hayati dengan materi:

a. Hama utama tanaman kelapa beserta cara pengendaliannya

b. Pemanfaatan potensi pengendali hayati dari golongan cendawan entomopatogen

c. Pengenalan cara identifikasi dan isolasi cendawan entomopatogen dari lapang

d. Cara perbanyakan cendawan entomopatogen secara sederhana untuk tingkat petani

Penyuluhan dilaksanakan pada malam hari mengingat kesibukan petani dalam menderes nira dan membuat gula kelapa pada siang hari. Penyuluhan dihadiri oleh semua anggota kelompok tani dan tidak hanya terbatas pada peserta saja sehingga transfer pengetahuan bisa mencapai khalayak sasaran lebih banyak. Peserta menunjukkan minat dan partisipasi yang tinggi yang ditandai dengan kehadiran peserta yang tetap bersemangat dari awal hingga akhir kegiatan. Peserta juga berperan aktif dalam melakukan diskusi terkait dengan materi yang telah disampaikan dalam kegiatan penyuluhan.

\section{B. Penyuluhan Pemanfaatan Limbah Pertanian dan Kotoran Ternak}

Penyuluhan berupa transfer pengetahuan mengenai cara pengelolaan kesuburan tanah selama dalam proses budidaya. Sedangkan penyuluhan tentang pemanfaatan limbah pertanian dan kotoran ternak dengan materi:

a. Limbah industri pertanian yang ada di sekitar lahan budidaya, seperti limbah jerami dan kawul jerami

b. Potensi pemanfaatan kotoran ternak sapi dan kotoran kambing sebagai bahan baku pupuk organik

c. Cara pembuatan pupuk organik dari jerami dan kotoran ternak yang banyak tersedia di lokasi mitra

d. Cara mempertahankan kesuburan tanah dengan penggunaan pupuk organik atau pemupukan secara berimbang.

Pembekalan pengetahuan yang dilaksanakan merupakan komunikasi dua arah sehingga petani bisa melaksanakan diskusi dan tanya jawab mengenai berbagai hal yang berkaitan dengan materi dan dilengkapi dengan hand out materi serta alat peraga yang mempermudah pemahaman dan memperjelas isi materi yang disampaikan pada khalayak sasaran.

2. Pembekalan Keterampilan

A. Perbanyakan Pengendali Hayati Secara Sederhana

Pembekalan keterampilan merupakan pelatihan perbanyakan cendawan entomopatogen $M$. anisopliae yang akan dimanfaatkan sebagai pengendali hayati hama kelapa. Perbanyakan secara sederhana dengan 
media perbanyakan beras jagung menghasilkan cendawan entomopatogen yang dapat digunakan oleh petani sebagai bahan pengendali pengganti pestisida kimia sintetik untuk menekan serangan hama kumbang badak pada tanaman kelapa.

buatan Media perbanyakan secara
entomopatogen cukup beragam seperti beras jagung, dedak padi dan serbuk gergaji, beras atau beras ketan namun dalam penerapan kegiatan ini dipilih media yang murah dan banyak tersedia di lokasi yaitu beras jagung. Pemilihan media perbanyakan tersebut akan memperlancar proses adaptasi teknologi dan membangkitkan minat dan partisipasi petani karena proses pembuatan pada tiap tahapan sederhana dan mudah dilaksanakan. Peralatan yang digunakan juga cukup sederhana dengan teknologi yang mudah diterapkan oleh petani. Keberhasilan produksi pengendali hayati akan membuka peluang usaha baru berupa produk cendawan entomopatogen yang dapat digunakan sebagai bahan tambahan dalam pupuk organik.

$$
\text { Pembekalan keterampilan }
$$
diikuti dengan baik oleh peserta. Meskipun demikian terdapat kendala dalam penerapannya seperti terjadinya kontaminasi hasil perbanyakan cendawan atau cendawan tidak tumbuh dan berkembang secara optimal. Hal tersebut terjadi karena petani masih belum terampil dalam inokulasi cendawan, sterilisasi media yang tidak sempurna dan pemasakan bahan media yang kurang tepat. Kendala kontaminasi dapat diatasi dengan latihan karena semakin sering berlatih maka keterampilan petani akan semakin meningkat.

\section{B. Pelatihan Pembuatan Pupuk Organik}

Pembuatan pupuk organik dimaksudkan untuk memanfaatkan limbah pertanian dan kotoran ternak. Ketersediaan kotoran ternak dan limbah pertanian di lokasi cukup berlimpah sehingga perolehan bahan tidak sulit. Pupuk organik yang sudah terfermentasi sempurna dan matang kemudian akan dianalisis untuk mengetahui kandungan masing-masing unsur hara makro, hara mikro, kandungan bahan organic, $\mathrm{C} / \mathrm{N}$ ratio pada tiap komposisi yang dibuat.

Tabel 2. Hasil Analisis Pupuk Organik

\begin{tabular}{|c|l|c|c|c|}
\hline \multirow{2}{*}{ No } & PARAMETER & \multicolumn{3}{|c|}{ HASIL ANALISIS (dalam \%) } \\
\cline { 3 - 5 } & $\begin{array}{c}\text { Jerami + } \\
\text { Kotoran } \\
\text { Sapi }\end{array}$ & $\begin{array}{c}\text { Jerami + } \\
\text { Kotoran } \\
\text { Kambing }\end{array}$ & $\begin{array}{c}\text { Jerami } \\
+ \\
\text { Kotoran } \\
\text { Puyuh }\end{array}$ \\
\hline 1 & C Organik & 22,69 & 24,78 & 26,85 \\
\hline 2 & C / N & 12,13 & 12,97 & 12,6 \\
\hline 3 & N-Total & 1,87 & 1,91 & 2,13 \\
\hline 4 & $\mathrm{P}_{2} \mathrm{O}_{5}$ & 2,01 & 2,14 & 2,82 \\
\hline 5 & $\mathrm{~K}_{2} \mathrm{O}$ & 2,89 & 2,49 & 2,96 \\
\hline
\end{tabular}

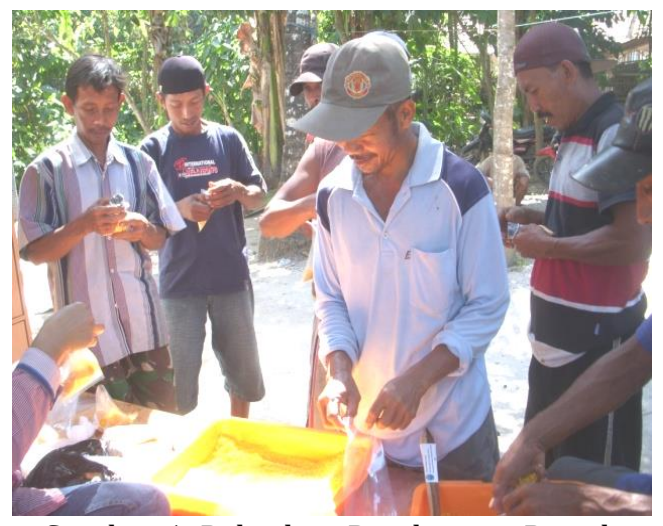

Gambar 1. Pelatihan Pembuatan Pupuk Organik dan Perbanyakan Pengendali Hayati

\section{Demplot}

Pupuk organik yang dihasilkan dalam pelatihan kemudian dicampur dengan pengendali hayati hasil pelatihan perbanyakan pengendali hayati yang telah dilakukan oleh mitra sebelumnya. Peragaan pencampuran dengan demplot sangat diperlukan agar homogenisasi berjalan sesuai target dan dihasilkan kompos plus pengendali hayati yang nantinya siap diaplikasikan sekaligus membuka peluang wirausaha pengembangan pupuk organik plus pengendali hayati. 


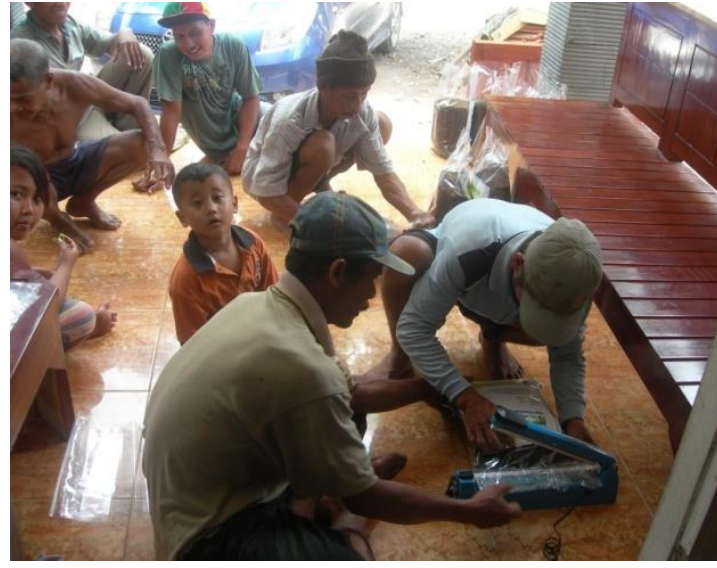

Gambar 2. Demplot Packing Produk Pupuk Organik Plus Pengendali Hayati

\section{Pendampingan}

Pendampingan dilakukan untuk menjamin transfer ipteks berjalan sesuai target dan sasaran sehingga mitra berhasil mandiri. Pendampingan dilakukan oleh tim pelaksana IbM terhadap mitra di lokasi kegiatan meliputi:

1. Transfer pengetahuan/penyuluhan

2. Transfer keterampilan/pelatihan

3. Demplot pencampuran pupuk organik dengan pengendali hayati

Petani atau mitra terkadang tidak telaten dengan pengembangan pertanian organik karena memerlukan pemahaman dan waktu yang lebih. Pendampingan harus dilakukan agar hasilnya sesuai dengan target yang telah ditetapkan.

Kegiatan pendampingan petani mitra ini bertujuan untuk mendampingi dan membimbing serta memberi petunjuk teknis pelaksanaan pembuatan pupuk organik, perbanyakan pengendali hayati, pencampuran pupuk organik plus pengendali hayati, pengemasan yang diusahakan oleh petani mitra. Dalam pelaksanaan kegiatan ini, pelaksana IbM memonitor setiap tahapan kegiatan agar pelaksanaan di lapang berjalan sesuai dengan tujuan yang telah ditetapkan.

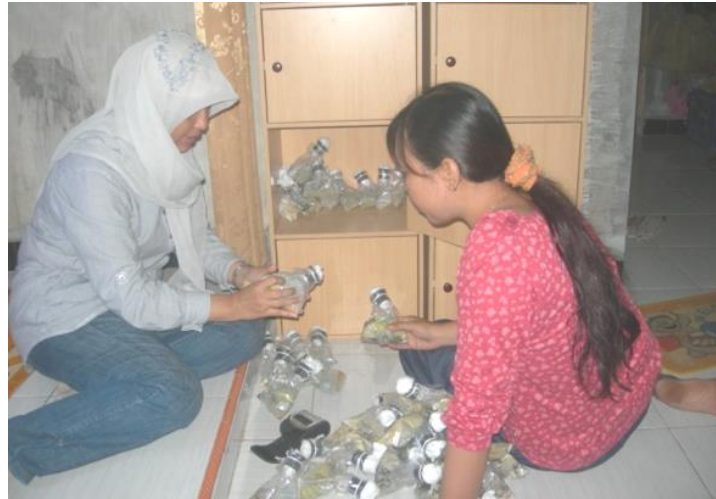

Gambar 3. Pendampingan Seleksi Pengendali Hayati

\section{Evaluasi Kegiatan}

Evaluasi dilakukan selama kegiatan berlangsung dengan menggunakan beberapa indikator evaluasi meliputi minat petani peserta, partisipasi petani peserta, keberhasilan pelatihan dengan meninjau langsung ke lokasi atau secara tidak langsung melalui diskusi dengan perangkat komunikasi telepon genggam. Selama berlangsungnya kegiatan Penerapan IbM, tim pelaksanaan program ini selalu memonitor dan bertanggung jawab terhadap pelaksanaan kegiatan pengabdian ini. Untuk selanjutnya dijalin kerja sama antara kelompok petani di Kecamatan Wuluhan dengan pihak Politeknik Negeri Jember secara berkelanjutan.

Teknologi yang diterapkembangkan berhasil ditransfer oleh tim pelaksana kegiatan dan diterima dengan baik oleh khalayak sasaran, dengan indikator keberhasilan yang tertera pada tabel 3 .

Tabel 3. Indikator Evaluasi dan Keberhasilan

\begin{tabular}{|c|l|l|}
\hline No & \multicolumn{1}{|c|}{ Materi } & \multicolumn{1}{c|}{ Tujuan } \\
\hline 1 & Pengenalan & a. Mitra dapat \\
& pengendali & \multicolumn{1}{c|}{ mengenal dan } \\
& mengetahui peranan \\
& Metarhizium & dan potensi \\
& anisopliae & cendawan \\
& Potensi limbah & $\begin{array}{l}\text { Metarhizium } \\
\text { anisopliae sebagai } \\
\end{array}$ \\
& pertanian dan & pengendali hayati \\
& kotoran ternak & hama kumbang \\
& & \\
\hline
\end{tabular}




\begin{tabular}{|c|c|c|}
\hline & & $\begin{array}{l}\text { badak pada tanaman } \\
\text { kelapa. } \\
\text { b. Mitra dapat } \\
\text { mengenal dan } \\
\text { mengetahui } \\
\text { pemanfaatan limbah } \\
\text { pertanian seperti } \\
\text { jerami dan } \\
\text { ketersediaan kotoran } \\
\text { ternak yang belum } \\
\text { dimanfaatkan secara } \\
\text { optimal sebagai } \\
\text { bahan baku } \\
\text { pembuatan pupuk } \\
\text { organik }\end{array}$ \\
\hline 2. & $\begin{array}{l}\text { Penerapan } \\
\text { perbanyakan } \\
\text { pengendali } \\
\text { hayati } \\
\text { Metarhizium } \\
\text { anisopliae } \\
\text { Pembuatan } \\
\text { pupuk organik } \\
\text { dari jerami dan } \\
\text { kotoran ternak }\end{array}$ & $\begin{array}{l}\text { a. Mitra dapat terampil } \\
\text { memperbanyak } \\
\text { pengendali hayati } \\
\text { Metarhizium } \\
\text { anisopliae secara } \\
\text { benar dan mandiri } \\
\text { b. Mitra dapat } \\
\text { menyebarluaskan } \\
\text { hasil kegiatan kepada } \\
\text { masyarakat lain yang } \\
\text { membutuhkan } \\
\text { c. Mitra dapat terampil } \\
\text { membuat kompos } \\
\text { dengan } \\
\text { memanfaatkan } \\
\text { limbah pertanian dan } \\
\text { kotoran ternak } \\
\text { secara benar dan } \\
\text { mandiri } \\
\text { d. Mitra dapat } \\
\text { menyebarluaskan } \\
\text { hasil kegiatan kepada } \\
\text { masyarakat lain yang } \\
\text { membutuhkan }\end{array}$ \\
\hline 3. & $\begin{array}{l}\text { Penerapan hal } \\
\text { lain yang } \\
\text { mendukung } \\
\text { keberhasilan } \\
\text { pengembangan } \\
\text { pupuk organik } \\
\text { plus } \\
\text { pengendali } \\
\text { hayati }\end{array}$ & $\begin{array}{l}\text { a. Mitra dapat } \\
\text { mengetahui } \\
\text { kebutuhan bahan, } \\
\text { kapasitas dan biaya } \\
\text { produksi, cara } \\
\text { penyimpanan dalam } \\
\text { pengembangan } \\
\text { pupuk organik plus } \\
\text { pengendali hayati. } \\
\text { b. Mitra dapat } \\
\text { meningkatkan } \\
\text { keamanan produk } \\
\text { dan lingkungan } \\
\text { pertanian dengan } \\
\text { menggunakan } \\
\text { produk yang lebih } \\
\text { ramah lingkungan } \\
\text { c. Khalayak sasaran } \\
\text { mempunyai peluang } \\
\text { untuk berwirausaha } \\
\text { dalam } \\
\text { pengembangan } \\
\text { pupuk organik plus } \\
\text { pengendali hayati }\end{array}$ \\
\hline
\end{tabular}

Berdasarkan hasil analisis
kelayakan dan evaluasi maka keberlanjutan kegiatan di mitra dapat diteruskan karena kegiatan transfer teknologi dalam Kelompok Tani Kelapa Rakyat di Kecamatan Wuluhan Kabupaten Jember berhasil dengan baik. Meskipun demikian masih terdapat beberapa kelemahan yang harus menjadi perhatian seperti keberlanjutan pengembangan pupuk organik plus pengendali hayati sehingga diperlukan dukungan dari berbagai pihak karena hasil aplikasi tidak dapat dilihat dalam kurun waktu pendek dibandingkan dengan pengendalian yang menggunakan pestisida kimia sintetik.

\section{KESIMPULAN DAN SARAN}

1. Kesimpulan

a. Pengembangan pupuk organik plus pengendali hayati sesuai diterapkan bagi mitra petani kelapa rakyat pada kelompok tani Rekesan Kepel dan kelompok tani Sulakdoro Kecamatan Wuluhan Kabupaten Jember.

b. Pembekalan pengetahuan, pembekalan keterampilan serta demo plot mengenai pengembangan pupuk organik plus pengendali hayati mendapat tanggapan yang baik dan antusias yang tinggi dari mitra.

c. Tujuan dari kegiatan sudah tercapai dan sesuai dengan kerangka pemecahan masalah yang telah dirumuskan meskipun masih terdapat kendala yang dapat diantisipasi melalui forum komunikasi dan latihan yang berkesinambungan dari khalayak sasaran dengan didukung oleh pembinaan dari pihak yang terkait.

\section{Saran}

a. Perluasan jaringan net working yang efektif bagi pengembangan pupuk kompos plus pengendali hayati 
melalui forum komunikasi yang berkelanjutan

b. Pembinaan dan kerjasama antar berbagai pihak yang berkepentingan perlu dipertahankan dan ditingkatkan guna mendorong terciptanya inovasi baru yang berkaitan dengan pemanfaatan pengendali hayati sebagai pengendali hama dan penyakit tanaman dan limbah pertanian sebagai bahan baku pupuk kompos.

\section{DAFTAR PUSTAKA}

Badan Pusat Statisitik Kabupaten Jember. 2013. Data dan Statistik Kabupaten Jember 2013. Badan Perencanaan Pembangunan Jember. Jember.

Dinas Perkebunan Propinsi Jawa Timur. 2012. Produksi Kelapa di Jawa Timur. Diakses 12 Maret 2014. http:///www.dinasperkebunanj atim
Dewan Kelapa Indonesia. 2009. Produktivitas Kelapa di Indonesia. Diakses 10 Maret 2014.

http://www.dewankelapaindon esia

Erawati, D.N. 2012. Improvement of Biological Control Technology Package by Environment Vision on Kasturi Tobacco Farm Management. Prosiding Seminar Internasional The Impacts of Regulations on Tobacco Control. Fakultas Kesehatan Masyarakat Universitas Jember: 316-321.

Kalshoven, L.G.E. 1981. The Pest of Crops in Indonesia. Rev. by van der Laan. PT. Ichtiar Baru van Hoeve. Jakarta. 